\title{
Blocking of iron uptake by monoclonal antibodies specific for the Neisseria meningitidis transferrin- binding protein 2
}

\author{
MAR PINTOR, LUCIA FERRÓN, J. A. GÓMEZ, A. GORRINGE*, M. TERESA CRIADO and C. M. \\ FERREIRÓS
}

Departamento de Microbiologia, Facultad de Farmacia, Universidad de Santiago de Compostela, Spain and * Centre for Applied Microbiology and Research, Porton Down, Salisbury, Wiltshire

\begin{abstract}
The existence of epitopes common to different strains in the Neisseria meningitidis transferrin (Tf)-binding protein 2 (TBP2), combined with the ability of polyclonal antiTBP2 antibodies to inhibit Tf binding and block iron uptake in this species, led to this study on the effect of anti-TBP1+2 monoclonal antibodies (MAbs) to determine the presence of epitopes inside the Tf-binding region. All MAbs used reacted exclusively with the homologous strain when tested by dot-blots of outer membrane vesicles, with the reaction being specific for TBP2 after SDS-PAGE and electroblotting. In contrast, ELISA and iron-uptake blocking assays were also positive with heterologous strains belonging to Rokbi's group II (high mol.wt TBP2). The results confirmed the two group classification proposed by Rokbi and, in contrast to other studies, indicated the existence of epitopes in the Tf-binding region that are common only to strains of Rokbi's group II. These epitopes may become denatured after drying for dot-blot assays or after SDSPAGE and electroblotting.
\end{abstract}

\section{Introduction}

Neisseria meningitidis is a gram-negative microorganism able to acquire iron directly from human transferrin (Tf) and lactoferrin [1] as a result of possessing specific receptors for these two proteins, namely the Tf-binding proteins (TBPs) and the lactoferrin-binding proteins (LBPs), synthesised when the bacteria grow in iron-limited media. The importance of the invasive phase in meningococcal meningitis has resulted in the structure, function and immunological properties of the TBPs receiving more attention than those of the LBPs. Interest in including iron-regulated proteins in anti-meningococcal vaccines is growing, and the TBPs are the most promising candidates [2]. TBP2 is a good immunogen, being one of the major outermembrane antigens in some strains [3-5]. This protein shows genetic, molecular and antigenic heterogeneity between strains $[4,6]$, allowing the classification of meningococci into two groups that are independent of serogroups, serotypes or strain origin. Group I (type strain B16B6) includes strains with a low mol.wt TBP2, while group II (type strain M982) includes strains with a higher mol. wt TBP2 $[6,7]$.

Despite the antigenic heterogeneity, the existence of only two TBP2 groups, much fewer than the number

Received 9 Jan. 1996; accepted 22 Feb. 1996.

${ }^{*}$ Corresponding author: Professor C. M. Ferreirós. found by any other grouping criteria, supports the possibility of using this protein as an antigen in vaccines. Some authors have reported the existence of antigenic domains common to the TBPs of all $N$. meningitidis strains [8,9]. Obviously, the TBP2 epitopes with the highest probability of being maintained with minimal or no changes are those corresponding to the Tf-binding site(s). The existence of these common epitopes, and the ability of polyclonal anti-TBP1+2 and anti-TBP2 antibodies to inhibit Tf-binding [10] and block iron uptake by the meningococci [11], led to this study on the effect of anti-TBP2 monoclonal antibodies (MAbs) in an attempt to identify the common epitopes and their relevance in Tf-binding and iron-uptake.

\section{Materials and methods \\ Bacterial strains and growth conditions}

The meningococcal strains used in this study were representative of different serogroups, serotypes and TBP2 groups (Table 1). N. meningitidis strain SD was provided by Dr D.A.A Ala'Aldeen (University of Nottingham). Strains were maintained at $-80^{\circ} \mathrm{C}$ and were then thawed and grown on Choc-Iso Agar plates (GC Medium base plus Biovitex; 1\% Biolife, Milan) $\mathrm{w} / \mathrm{v}$ incubated for $24 \mathrm{~h}$ at $37^{\circ} \mathrm{C}$ in air with $\mathrm{CO}_{2} 5 \% \mathrm{v} / \mathrm{v}$. One freshly grown isolated colony was used to inoculate flasks containing Mueller-Hinton broth 
Table 1. Characteristics of the $N$. meningitidis strains used in the study

\begin{tabular}{lcclcc}
\hline Strain & Serogroup & Serotype & Origin & TBP2 (MDa) & Rokbi's group \\
\hline P000 & B & $15: \mathrm{p} ?$ & Oropharynx & 83.8 & II \\
P391 & AA & $15: \mathrm{p} ?$ & Oropharynx & 84.9 & II \\
SD & B & $15: \mathrm{p} 1.16$ & CSF & 78.0 & II \\
V002 & B & $15: \mathrm{p} ?$ & CSF & 63.0 & I \\
HG7 & C & $2 \mathrm{~b} p 1.2$ & CSF & 63.4 & I \\
B16B6 & B & 2a:p1.2 & CSF & I \\
\hline
\end{tabular}

$\mathrm{AA}$, autoagglutinable; CSF, cerebrospinal fluid.

(MH) with $39 \mu \mathrm{M}$ ethylene-diamine-dihydroxy-phenyl acetic acid (MH-EDDA; iron restriction). The flasks were then incubated in a water bath for $14 \mathrm{~h}$ at $37^{\circ} \mathrm{C}$ with constant shaking at $100 \mathrm{rpm}$.

For iron-uptake blocking experiments, a modified Morse and Bartenstein defined medium deferrated by treatment with Chelex-100 ion-exchange resin (Bio$\mathrm{Rad})$ was used (mMBDM) [12]. After growth of the bacteria in MH-EDDA for $12 \mathrm{~h}, 4 \mathrm{ml}$ of the resulting culture were inoculated into $250-\mathrm{ml}$ Erlenmeyer flasks containing $100 \mathrm{ml}$ of mMBDM. The flasks were incubated for $6 \mathrm{~h}$ in a water bath at $37^{\circ} \mathrm{C}$ with constant shaking at $100 \mathrm{rpm}$ to exhaust the intracellular iron pool. The bacteria were recovered by centrifugation at $10000 \mathrm{~g}$ for $10 \mathrm{~min}$ and resuspended for the assays in fresh mMBDM at a concentration of $10^{10}$ cells $/ \mathrm{ml}$. Viability was estimated to be $>95 \%$ by comparison of direct microscopy and colony counting.

\section{Outer-membrane protein (OMP) preparations}

Excreted outer-membrane vesicles ('blebs') and fragmented bacterial outer membranes were obtained from the cultures by $\mathrm{LiCl}$ extraction [13]. Briefly, the cultures were centrifuged at $48000 \mathrm{~g}$ for $1 \mathrm{~h}$ and the pellets were resuspended in $0.1 \mathrm{M}$ acetate buffer $(\mathrm{pH}$ 5.8) with $0.2 \mathrm{M} \mathrm{LiCl}$, incubated at $45^{\circ} \mathrm{C}$ for $2 \mathrm{~h}$ in a water-bath with shaking, passed through a 21-gauge needle, and centrifuged at $10000 \mathrm{~g}$ for $15 \mathrm{~min}$. The supernates, containing 'blebs' and membrane fragments, were centrifuged at $200000 \mathrm{~g}$ for $10 \mathrm{~min}$. The pellets were then resuspended in $\mathrm{H}_{2} \mathrm{O}$ and stored in small volumes at $-20^{\circ} \mathrm{C}$.

\section{Immune serum and MAbs}

A rabbit polyclonal serum against the biologically active TBP1+2 complex of $N$. meningitidis strain SD was obtained from Dr D.A.A Ala'Aldeen. This serum was raised by inoculating a New Zealand White male rabbit with five doses of the streptavidin-agaroseTBP1+2 complex by subcutaneous injection [14]. All MAbs were specific for the TBPs from $N$. meningitidis strain SD and were produced and characterised as described previously $[15,16]$. The characteristics of the MAbs are given in Table 2. A mouse non-immune serum was used as a negative control.

\section{Preparation of $\left[{ }^{55} \mathrm{Fe}\right]\left(\mathrm{Fe}_{2}\right)-\mathrm{Tf}$}

$\left[{ }^{55} \mathrm{Fe}\right]\left(\mathrm{Fe}_{2}\right)$-Tf was prepared as described previously [17]. For each $\mathrm{mg}$ of apo-Tf (Sigma) dissolved in buffer (Tris $40 \mathrm{mM}, \mathrm{pH} \mathrm{7.4;2} \mathrm{mm}$ sodium bicarbonate), $0.0075 \mu \mathrm{mol}$ of $\left[{ }^{55} \mathrm{Fe} \mathrm{FeCl}_{3} \quad(1.5 \mu \mathrm{Ci} / \mu \mathrm{g} \mathrm{Fe}\right.$; Amersham) and $0.075 \mu \mathrm{mol}$ of sodium citrate were added. This mixture was incubated at room temperature for $30 \mathrm{~min}$, dialysed against the same buffer for $16 \mathrm{~h}$, then against mMBDM for another $6 \mathrm{~h}$, and finally sterilised by filtration through $0.45-\mu \mathrm{m}$ nitrocellulose filters. Iron saturation of $\mathrm{Tf}$ was determined to be $25 \%$ after counting the radioactivity associated with $\mathrm{Tf}$ and determining the precise Tf concentration.

\section{SDS-PAGE and immunoblotting}

OMPs were analysed by SDS-PAGE on acrylamide $10 \% \mathrm{w} / \mathrm{v}$ gels with the discontinuous buffer system of Laemmli [18]. Samples containing $20 \mu \mathrm{g}$ of protein were either boiled at $100^{\circ} \mathrm{C}$ for $15 \mathrm{~min}$, heated at $37^{\circ} \mathrm{C}$ for $20 \mathrm{~min}$, or maintained overnight at room temperature in sample buffer before electrophoresis, depending on the strain [4]. After electrophoresis, the proteins were transferred from the gels to nitrocellulose membranes with a Milliblot-SDE electroblotting system (Millipore) and a low ionic strength discontinuous buffer system comprising two

Table 2. Characteristics of the polyclonal serum and MAbs against the TBP1+2 complexes obtained from $N$. meningitidis strain $\mathrm{SD}$

\begin{tabular}{|c|c|c|c|c|c|}
\hline \multirow[b]{2}{*}{ Serum } & \multirow{2}{*}{$\begin{array}{l}\text { Immunoglobulin } \\
\text { type }\end{array}$} & \multicolumn{3}{|c|}{ ELISA titres } & \multirow{2}{*}{$\begin{array}{c}\text { Bactericidal } \\
\text { titre }\end{array}$} \\
\hline & & TBP $1+2$ & TBP1 & TBP2 & \\
\hline Rabbit & Polyclonal & $3.08 \times 10^{5}$ & . & & 10 \\
\hline MAb8 & $\operatorname{IgG} 2 a$ & $1.46 \times 10^{5}$ & $<6$ & $1.26 \times 10^{5}$ & $<10$ \\
\hline MAbll & $\operatorname{IgG} 2 a$ & $1.11 \times 10^{5}$ & $<6$ & $2.70 \times 10^{4}$ & $<10$ \\
\hline MAbI03 & $\operatorname{IgG} 2 a$ & $1.84 \times 10^{5}$ & $<6$ & $3.18 \times 10^{4}$ & $<10$ \\
\hline MAb 109 & $\operatorname{IgM}$ & $2.30 \times 10^{3}$ & 47 & 30 & $<10$ \\
\hline MAbl10 & IgM & $1.24 \times 10^{4}$ & 206 & $8.03 \times 10^{3}$ & $<10$ \\
\hline MAb 112 & IgG 1 & $8.30 \times 10^{4}$ & 39 & $8.73 \times 10^{4}$ & $<10$ \\
\hline
\end{tabular}


anode buffers $(0.3 \mathrm{M}$ Tris plus methanol $10 \% \mathrm{v} / \mathrm{v}, \mathrm{pH}$ 10.4 , and $25 \mathrm{mM}$ Tris plus methanol $10 \% \mathrm{v} / \mathrm{v}, \mathrm{pH} 10.4$ ) and one cathode buffer ( $25 \mathrm{mM}$ Tris, $40 \mathrm{mM}$ 6-aminohexanoic acid, methanol $20 \% \mathrm{v} / \mathrm{v}, \mathrm{pH} 9.4$ ), according to the instructions provided by the manufacturer. Electroblotting was performed for $30 \mathrm{~min}$ at $2.5 \mathrm{~mA} / \mathrm{cm}^{2}$ of gel area.

Transferred proteins were immunoblotted with the rabbit anti-TBP1+2 serum or the MAbs. Both serum and antibodies were diluted in TBS-Tween blocking buffer (Tris-buffered saline containing skimmed milk $0.5 \% \mathrm{w} / \mathrm{v}$, antifoam A $0.001 \% \mathrm{v} / \mathrm{v}$ and Tween 20 $500 \mathrm{~g} / \mathrm{L}$ ) and incubated with the membranes at $37^{\circ} \mathrm{C}$ for $1.5 \mathrm{~h}$. Bound antibodies were visualised with peroxidase-conjugated goat anti-rabbit or anti-mouse immunoglobulins (Dakopatts, Glostrup, Denmark) and developed with chloronaphthol [19].

\section{Dot-blot assays}

Samples ( $2 \mu \mathrm{l}$ containing $1 \mu \mathrm{g}$ total protein) of outermembrane suspensions were spotted on to nitrocellulose disks placed inside the wells of polystyrene microtitration plates. The disks were then incubated for $1 \mathrm{~h}$ with $100 \mu \mathrm{l}$ of the polyclonal serum or the MAbs, diluted in blocking solution and developed as described above for immunoblots.

\section{Liquid-phase whole cell ELISA}

This assay was performed as described previously [20] with MultiScreen-HV Filtration Plates and $0.45-\mu \mathrm{m}$ Durapore membranes (Millipore). Briefly, exponential phase cultures in MH-EDDA were harvested by centrifugation at $10000 \mathrm{~g}$ for $10 \mathrm{~min}$. The pellet was washed twice and resuspended to $10^{8}$ cells $/ \mathrm{ml}$ in TBSTween. Portions $(100 \mu \mathrm{l})$ of the suspension were added to the same volume of MAb dilutions in bovine serum albumin $1 \% \mathrm{w} / \mathrm{v}$ in TBS-Tween (TBS-Tween-BSA) in the wells of a filtration plate, blocked previously with TBS-Tween-BSA, and the mixtures were incubated overnight at $37^{\circ} \mathrm{C}$. The suspensions were then filtered and the bacterial cells were washed once with TBSTween before incubation for $5 \mathrm{~h}$ at $37^{\circ} \mathrm{C}$ with $100 \mu \mathrm{l}$ of horseradish peroxidase-conjugated rabbit anti-mouse immunoglobulins diluted in TBS-Tween-BSA. Finally, the cells were washed twice with $200 \mu$ of TBS-Tween and assayed by addition of $100 \mu \mathrm{l}$ of 5 -aminosalicyclic acid $(1 \mathrm{~g} / \mathrm{L}$ in $10 \mathrm{mM}$ sodium phosphate, $\mathrm{pH} 6.0$, $100 \mathrm{mM}$ EDTA) for $1 \mathrm{~h}$ at room temperature. The reaction was stopped by the addition of $0.3 \mathrm{M} \mathrm{NaOH}$ and the absorbance values of the filtrates were read at $450 \mathrm{~nm}$ in a microtitration plate reader.

\section{Bactericidal assays}

These were performed essentially as described for gonococci by Veale et al. [21]. Normal human serum (NHS) was pooled from three donors who were shown to have low levels of antibodies to meningococcal outer-membrane vesicles. Strain SD was grown in Mueller-Hinton broth containing EDDA $5 \mu \mathrm{g} / \mathrm{ml}$, washed and resuspended in gonococcal defined medium to $c$. $4 \times 10^{4}$ cells $/ \mathrm{ml}$. Serial dilutions of MAbs were prepared in a microtitration plate and bacteria were added to a final concentration of $10^{4}$ cells $/ \mathrm{ml}$ and NHS to $20 \% \mathrm{v} / \mathrm{v}$. The percentage of bacteria surviving was compared with a control containing heat-inactivated NHS after incubation for $1 \mathrm{~h}$ at $37^{\circ} \mathrm{C}$.

\section{Iron uptake blocking assay}

The ability of the rabbit immune serum (antiTBP1+TBP2) and the MAbs to block iron uptake from Tf was determined as described previously [11]. Briefly, $100-\mu$ l volumes of a 1 in 2 dilution of the inactivated $\left(56^{\circ} \mathrm{C}\right.$ for $\left.30 \mathrm{~min}\right)$ serum or a 1 in 5 dilution of the MAbs in deferrated mMBDM were incubated with $100 \mu \mathrm{l}$ of bacterial suspension $\left(10^{9}\right.$ cells) in 1.5 $\mathrm{ml}$ polypropylene Eppendorf tubes for $1.5 \mathrm{~h}$ at $37^{\circ} \mathrm{C}$, after which $100 \mu \mathrm{l}$ of a ${ }^{55} \mathrm{Fe}$-Tf solution were added and the mixtures were incubated at room temperature for $1 \mathrm{~h}$. Iron uptake was stopped by recovery of the bacteria by centrifugation in a microfuge and washing twice with cold mMBDM. The bacterial pellet was suspended in $200 \mu \mathrm{l}$ of $\mathrm{H}_{2} \mathrm{O}$, added to $4 \mathrm{ml}$ of scintillation cocktail (Ready-protein ${ }^{\mathrm{TM}}$; Beckman), and the associated radioactivity was determined by liquid scintillation counting. Controls for non-specific blocking contained normal (non-immune) mouse serum. All experiments were performed with iron-free materials and apparatus.

\section{Statistical analysis}

Estimation of the significance of differences was with Student's $t$ test [22].

\section{Results}

\section{Antigenic heterogeneity and immunogenic epitopes of the TBPs}

The anti-TBP1+2 serum and MAbs both showed high titres in dot-blot and Western blot assays, with working titres of 1 in 1000 although lower serum dilutions were required for the evaluation of ironuptake blocking.

Fig. 1 shows the results obtained in Western blot experiments with the polyclonal anti-TBP1+2 (strain SD) serum. A strong cross-reaction was seen with the three strains belonging to Rokbi's group II (including strain SD), but no reaction was seen with the three strains from Rokbi's group I. All MAbs reacted exclusively with the homologous strain SD (results not shown). Table 3 summarises the results of dot-blot experiments, confirming the Western blot results. 


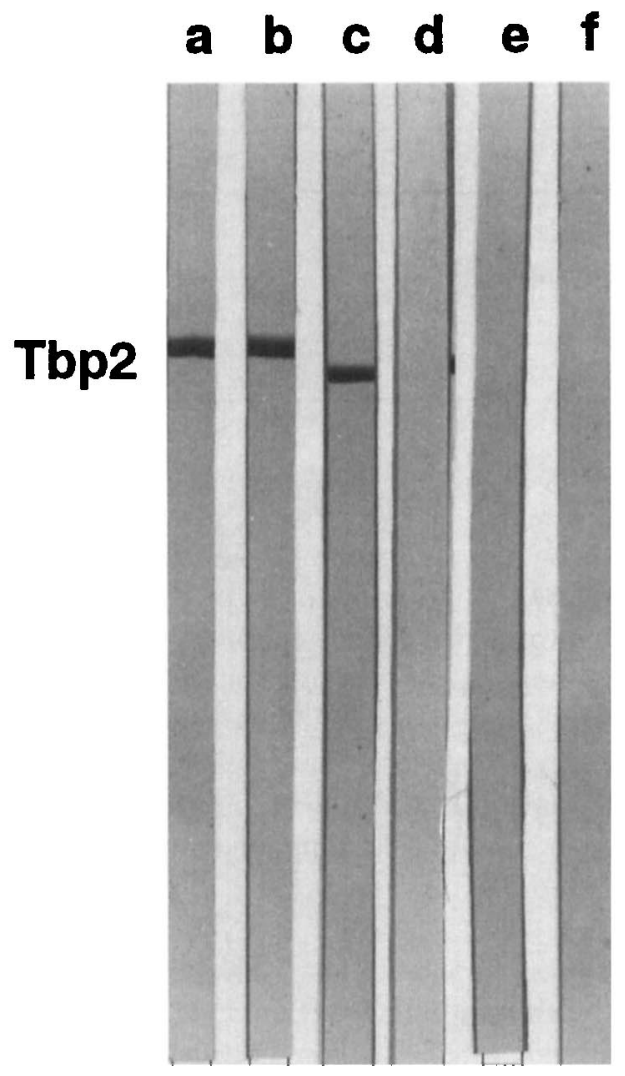

Fig. 1. Antigenic profiles obtained for $N$. meningitidis strains in Western blot experiments with the polyclonal anti-TBP1+2 rabbit serum derived from strain SD. Strains: a, P000; b, P391; c, SD; d, HG7; e, V002; and $\mathbf{f}, \mathrm{B} 16 \mathrm{~B} 6$.

\section{Liquid-phase whole cell ELISA}

Table 4 shows the reactivities of MAbs 103 and 110 in a liquid phase whole cell ELISA. MAb103 reacted with the three strains belonging to Rokbi's group II (i.e., strains P000, P391 and SD). A similar, but weaker reaction was obtained with MAb110. Neither MAb reacted with the two Rokbi's group I strains tested.

\section{Inhibition of iron uptake}

The immune serum and MAbs were titrated in preliminary experiments against the homologous strain, resulting in working titres of 1 in 2 for the polyclonal anti-TBP1+2 serum and 1 in 5 for the MAbs (some of
Table 4. Liquid-phase whole cell ELISA cross-reactivity of MAbs 103 and 110 with strains of $N$. meningitidis

\begin{tabular}{lccc}
\hline & & \multicolumn{2}{c}{ Reactivity with } \\
\cline { 3 - 4 } Strain & Rokbi's group & MAb103 & MAb110 \\
\hline P000 & II & + & \pm \\
P391 & II & + & \pm \\
SD & II & ++ & ++ \\
V002 & I & - & - \\
HG7 & I & - & - \\
\hline
\end{tabular}

++, strong; +, good; \pm , weak; -, negative.

the MAbs had higher titres of up to 1 in 20 , but 1 in 5 was chosen to maintain consistent $\mathrm{MAb}$ dilutions). Bacterial suspensions for the experiments were completely iron-exhausted, as demonstrated by their inability to continue growing after passage through the culture plates with Desferal.

Table 5 shows the results obtained in the iron-uptake inhibition experiments. A non-immune mouse serum was used as the $100 \%$ uptake $(0 \%$ blockage) control. The results of statistical tests indicated that only an uptake inhibition of $>60 \%$ was statistically significant $(\mathrm{p}<0.05)$. The polyclonal anti-TBP1+2 rabbit serum blocked iron uptake by the homologous strain only, whereas some MAbs blocked iron uptake, with variable efficacy, by heterologous strains belonging to Rokbi's group II, with MAbs103, 110 and 112 being the most effective.

\section{Discussion}

The latest anti-meningococcal outer-membrane based vaccines [23-27] demonstrated the necessity to direct the immune response against epitopes able to specifically induce protective bactericidal antibodies, so avoiding the production of many non-functional antibodies occurring in polyclonal sera. The meningococcal iron-regulated OMPs that form the Tf-receptor complex are highly immunogenic $[2-4,28]$ and are necessary for Tf-binding and iron internalisation [29-32]. Recent studies have shown the protective and bactericidal effects of TBP2-specific antibodies [2], as well as their ability to inhibit binding of $\mathrm{Tf}$ to the receptor complex and iron uptake by the bacteria, thereby stopping bacterial growth $[10,11,33]$. The

Table 3. Dot-blot analysis of the cross-reactivity of the rabbit polyclonal serum and MAbs with strains of $N$. meningitidis

\begin{tabular}{lccccc}
\hline & & \multicolumn{4}{c}{ Reactivity of serum and MAbs } \\
\cline { 3 - 6 } Strain & Rokbi's group & Polyclonal & MAb103 & MAb110 & MAb112 \\
\hline P000 & II & + & - & - & - \\
P391 & II & + & - & - & - \\
SD & II & + & + & + & + \\
V002 & I & - & - & - & - \\
HG7 & I & - & - & - & - \\
B16B6 & I & - & - & - & - \\
\hline
\end{tabular}


Table 5. Iron-uptake blocking produced by the polyclonal anti-TBP1+2 serum and MAbs with strains of N. meningitidis

\begin{tabular}{|c|c|c|c|c|c|c|c|c|}
\hline \multirow[b]{2}{*}{ Strain } & \multirow{2}{*}{$\begin{array}{c}\text { Rokbi's } \\
\text { group }\end{array}$} & \multicolumn{7}{|c|}{ Percentage inhibition of iron uptake by } \\
\hline & & TBPI+2 & MAb8 & MAb11 & MAb103 & MAb109 & MAb1 10 & MAbl12 \\
\hline $\mathrm{P} 000$ & II & 17 & 18 & 22 & $58^{*}$ & 33 & 34 & $70^{*}$ \\
\hline P391 & II & 0 & $66^{*}$ & $66^{*}$ & $57^{*}$ & $72^{*}$ & $61^{*}$ & $61^{*}$ \\
\hline $\mathrm{SD}$ & II & $70^{*}$ & 16 & 7 & $70^{*}$ & 0 & $69^{*}$ & $83^{*}$ \\
\hline V002 & I & 0 & 0 & 0 & 0 & 0 & 0 & 0 \\
\hline HG7 & I & 0 & 0 & 0 & 15 & 0 & 11 & 15 \\
\hline B16B6 & I & 0 & 0 & 0 & 0 & 0 & 2 & 33 \\
\hline
\end{tabular}

${ }^{*}$ Statistically significant $(p<0.05)$.

TBP2 protein is, therefore, considered to be a good candidate for inclusion in anti-meningococcal vaccines.

Despite the existence of two meningococcal TBP2 classes, defined by their molecular mass, antigenic properties and genetic sequence [6], all strains show $47 \%$ TBP2 homology [30]. A highly structured and extremely stable TBP2 domain of c. 270-290 amino acids is conserved between very divergent polypeptides. This is presumably involved in Tf-binding, suggesting that the Tf-binding epitope could be common to all $N$. meningitidis strains [34]. The main problem presented by many OMPs is that the immunedominant epitopes exposed to the surface are strainspecific, e.g., the $70-\mathrm{kDa}$ meningococcal protein $[35,36]$. The present study analysed the conservation of the TBP2 epitopes for Tf-binding, and their surface accessibility, with MAbs and four different techniques.

Western-blot and dot-blot results showed that all the MAbs tested reacted only with the original homologous strain, whereas the rabbit polyclonal antiTBP $1+2$ serum reacted with the TBP2 of all strains from the same Rokbi group as the immunising strain (group II), suggesting that the MAbs could be reacting with strain-specific epitopes. Alternatively, they could be recognising conformational epitopes made nonreactive by electrodenaturation in the Western blot or by drying in the dot-blot techniques. Electrophoretic denaturation of the TBP2 from some strains has been reported [4,34], and it seems from our study that drying can also affect the TBP2 immune reactivity, as also observed previously [37]. The observed reaction with the homologous strain could be explained by the higher affinity of the MAbs for their corresponding epitope and possibly by a higher molar amount of those specific epitopes.

All denaturation problems were overcome with a liquid-phase ELISA and whole cell suspensions [20], thereby avoiding denaturation of the TBP2 protein and mimicking the in-vivo conditions more realistically. In this assay, all MAbs reacted with both the homologous strain and the heterologous strains belonging to Rokbi's group II. The possible existence of conformational epitopes denatured by electrotransference or drying was also supported by the observation that
MAb109 bound exclusively to TBP $1+2$ complexes, a fact explicable only on the basis of an interaction with conformational or shared epitopes. Thus it is important to emphasise that solid-phase assays (dot-blots and Western blots) do not provide conclusive results in cross-reactivity studies. These results further support the two-group classification of meningococcal strains proposed by Rokbi and supported by other investigations $[3,4,6,38]$.

It has been reported that rabbit polyclonal antiTBP $1+2$ and anti-TBP2 sera inhibited Tf-binding and bacterial growth in the homologous strain [10]. The present study indicated that the rabbit anti-TBP $1+2$ polyclonal serum blocked iron uptake only in the homologous strain, but previous studies have demonstrated that anti-TBP1+2 and anti-TBP2 mouse polyclonal sera inhibited Tf-binding, blocked iron uptake and impeded bacterial growth in all strains belonging to the same Rokbi group $[11,12]$. The liquid-phase ELISA assay used in the present study demonstrated that, of the six MAbs tested, three (MAbs 103, 110 and 112) were able to block iron uptake by all strains from Rokbi's group II, but by none of the strains from Rokbi's group I. This agreed with the results of the $\mathrm{MAb}$ binding assays, thereby indicating, in contrast to previous results [34], that the Tf-binding site is not conserved in all $N$. meningitidis strains. Furthermore, cross-blocking of iron uptake by the MAbs, in contrast to the rabbit polyclonal serum, confirmed the diversity in the immune reactioned elicited in different animal models and the necessity to choose appropriate models for the study of the different antigens $[28,39]$.

The polyclonal rabbit anti-TBP1+2 serum showed a bactericidal titre that was 10 -fold lower than that of sera raised against whole outer-membrane vesicles, and none of the MAbs showed appreciable bactericidal titres. This contrasts with the fact that some of the MAbs are IgM or IgG2a, well known complementactivating immunoglobulins. Eliciting bactericidal antibodies is an important requirement for antigens which are intended to be included in vaccines [35]. More detailed analysis is required to resolve the conflicts mentioned above and to analyse the specific epitopes to which the MAbs bind. 
This paper was supported by grants XUGA 20309 B95 and FIS96/ 1146. We are grateful to Dr DAA Ala'Aldeen for providing us with the rabbit polyclonal immune serum.

\section{References}

1. Mickelsen PA, Sparling PF. Ability of Neisseria gonorrhoeae, Neisseria meningitidis, and commensal Neisseria species to obtain iron from transferrin and iron compounds. Infect Immun 1981; 33: 555-564.

2. Danve $\mathrm{B}$, Lissolo L, Mignon $\mathrm{M}$ et al. Transferrin-binding proteins isolated from Neisseria meningitidis elicit protective and bactericidal antibodies in laboratory animals. Vaccine 1993, 11: 1214-1220.

3. Griffiths E, Stevenson P, Ray A. Antigenic and molecular heterogenicity of the transferrin-binding protein of Neisseria meningitidis. FEMS Microbiol Lett 1990; 69: 31-36.

4. Ferrón L, Ferreirós CM, Criado MT, Pintor M. Immunogenicity and antigenic heterogeneity of a human transferrin-binding protein in Neisseria meningitidis. Infect Immun 1992; 60: 2887-2892.

5. Ferreirós CM, Ferrón L, Criado MT. In vivo human immune response to transferrin-binding protein 2 and other ironregulated proteins of Neisseria meningitidis. FEMS Immunol Med Microbiol 1994; 8: 63-68.

6. Rokbi B, Mazarin V, Maitre-Wilmotte G, Quentin-Millet M-J. Identification of two major families of transferrin receptors among Neisseria meningitidis strains based on antigenic and genomic features. FEMS Microbiol Lett 1993; 110: 51-58.

7. Quentin-Millet MJ, Lissolo L, Legrain $\mathrm{M}$ et al. Transferrinbinding proteins of Neisseria meningitidis. In: Evans JS, Yost SE, Maiden MCJ, Feavers IM (eds) The 9th International Pathogenic Neisseria Conference, Winchester. 1994: 137-139.

8. Stevenson $P$, Williams $P$, Griffiths E. Common antigenic domains in transferrin-binding protein 2 of Neisseria menin gitidis, Neisseria gonorrhoeae, and Haemophilus influenzae type b. Infect Immun 1992; 60: 2391-2396.

9. Holland J, Langford PR, Towner KJ, Williams P. Evidence for in vivo expression of transferrin-binding proteins in Haemophilus influenzae type b. Infect Immun 1992; 60: 2986-2991.

10. Lissolo L, Maitre-Wilmotte G, Dumas P, Mignon M, Danve B, Quentin-Millet M-J. Evaluation of transferrin-binding protein 2 within the transferrin-binding protein complex as a potential antigen for future meningococcal vaccines. Infect Immun 1995; 63: $884-890$

11. Pintor M, Ferrón L, Gómez JA et al. Blocking of iron uptake from transferrin by antibodies against the transferrin binding proteins in Neisseria meningitidis. Microb Pathog (in press).

12. Pintor $\mathrm{M}$, Ferreirós $\mathrm{CM}$, Criado MT. Energy-independent binding of iron complexed to small organic chelants by Neisseria meningitidis. J Gen Appl Microbiol 1994; 40: 23-34.

13. Ferreirós CM, Criado MT, Del Rio MT, Pintor M. Analysis of the expression of outer-membrane proteins in Neisseria meningitidis in iron-replete and iron-deficient media. FEMS Microbiol Lett 1990; 71: 49-54

14. Ala'Aldeen DAA, Powell NBL, Wall RA, Borriello SP. Localization of the meningococcal receptors for human transferrin. Infect Immun 1993; 61: 751-759.

15. Smith AW, Wilton J, Clark SA, Alpar O, Melling J, Brown MRW. Production and characterization of monoclonal antibodies to outer membrane proteins of Pseudomonas aerugi nosa grown in iron-depleted media. J Gen Microbiol 1991; 137: $227-236$

16. Gorringe AR, Irons LI, Aisen $\mathrm{P}$, Zak $\mathrm{O}$, Robinson A. Purification of Neisseria meningitidis transferrin binding proteins and characterization by epitope mapping and iron release studies. In: Evans JS, Yost SE, Maiden MCJ, Feavers IM (eds) The 9th International Pathogenic Neisseria Conference, Winchester. 1994: 140-142.

17. Pintor M, Ferreirós CM, Criado MT. Characterization of the transferrin-iron uptake system in Neisseria meningitidis. FEMS Microbiol Lett 1993; 112: 159-166.

18. Laemmli UK. Cleavage of structural proteins during the assembly of the head of the bacteriophage T4. Nature 1970; 227: $680-685$.

19. Wood JN, Solid-phase screening of monoclonal antibodies. In: Walker JM (ed) Methods in molecular biology, vol 1. Clifton,
NJ, Human Press. 1984: 279-286

20. Pintor M, Ferreirós CM, Criado MT, Ferrón L. Expression levels of human transferrin receptors in Neisseria species. $J$ Microbiol Methods 1992; 15; 321-326.

21. Veale DR, Penn CW, Smith H. Factors affecting the induction of phenotypically determined serum resistance of Neisseria gonorrhoeae grown in media containing serum or its diffusible components. J Gen Microbiol 1981; 122: 235-245.

22. Sokal RR, Rohlf FJ. Single-classification analysis of variance. In: Sokal RR, Rohlf FJ (eds) Biometry. New York, W.H. Freeman and Co. 1995: 207-271.

23. Zollinger W, Boslego J, Moran E et al. Meningococcal serogroup B vaccine: protection trial and follow-up studies in Chile. NIPHS Annals 1991; 14: 211-213.

24. Fernández de Cossio ME, Ohlin $\mathrm{M}$, Llano $\mathrm{M}$ et al. Human monoclonal antibodies against an epitope on the class $5 \mathrm{c}$ outer membrane protein common to many pathogenic strains of Neisseria meningitidis. J Infect Dis 1992; 166: 1322-1328.

25. Christodoulides M, McGuinness BT, Heckels JE. Immunization with synthetic peptides containing epitopes of the class 1 outer-membrane protein of Neisseria meningitidis: production of bactericidal antibodies on immunization with a cyclic peptide. J Gen Microbiol 1993; 139: 1729-1738.

26. Christodoulides $M$, Heckels JE. Immunization with a multiple antigen peptide containing defined B- and T-cell epitopes: production of bactericidal antibodies against group B Neisseria meningitidis. Microbiology 1994; 140: 2951-2960.

27. Delvig AA, Wedege E, Caugant DA et al. A linear B-cell epitope on the class 3 outer-membrane protein of Neisseria meningitidis recognized after vaccination with the Norwegian group B outer-membrane vesicle vaccine. Microbiology 1995; 141: $1593-1600$

28. Ala'Aldeen DAA, Stevenson $\mathrm{P}$, Griffiths $\mathrm{E}$ et al. Immune responses in humans and animals to meningococcal transferrinbinding proteins: implications for vaccine design. Infect Immun 1994; 62: 2984-2990.

29. Irwin SW, Averil N, Cheng CY, Schryvers AB. Preparation and analysis of isogenic mutants in the transferrin receptor proteins genes, $t b p A$ and $t b p B$, from Neisseria meningitidis. Mol Microbiol 1993; 8: 1125-1133.

30. Legrain $\mathrm{M}$, Mazarin V, Irwin SW et al. Cloning and characterization of Neisseria meningitidis genes encoding the transferrin-binding proteins Tbpl and Tbp2. Gene 1993; 130: 73-80.

31. Anderson JE, Sparling PF, Cornelissen CN. Gonococcal transferrin-binding protein 2 facilitates but is not essential for transferrin utilization. $J$ Bacteriol 1994; 176: 3162-3170.

32. Pettersson A, Maas A, Tommassen J. Identification of iroA gene product of Neisseria meningitidis as a lactoferrin receptor. J Bacteriol 1994; 176: 1764-1766.

33. Ferreirós CM Criado MT, Ferrón L, Pintor M. Blocking of iron uptake from transferrin by antibodies against the transferrinbinding system of Neisseria meningitidis. The 9th International Pathogenic Neisseria Conference, Winchester. 1994: 166-167.

34. Vonder Haar RA, Legrain M, Kolbe HVJ, Jacobs E. Characterization of a highly structured domain in Tbp2 from Neisseria meningitidis involved in binding to human transferrin. J Bacteriol 1994; 176: 6207-6213.

35. Pettersson A, Kuipers B, Pelzer $\mathrm{M}$ et al. Monoclonal antibodies against the 70-kilodalton iron-regulated protein of Neisseria meningitidis are bactericidal and strain specific. Infect Immun 1990; 58: 3036-3041.

36. Ala'Aldeen DAA, Davies HA, Borriello SP. Vaccine potential of meningococcal FrpB: studies on surface exposure and functional attributes of common epitopes. Vaccine 1994; 12: 535-541.

37. Cornelissen $\mathrm{CN}$, Sparling PF. Iron piracy: acquisition of transferrin-bound iron by bacterial pathogens. Mol Microbiol 1994; 14: 843-850.

38. Ferreirós CM, Criado MT, Pintor M, Ferrón L. Analysis of the molecular weight heterogeneity of the transferrin receptor in Neisseria meningitidis and commensal Neisseria. FEMS Microbiol Lett 1991; 83: 247-254.

39. Ferrón L, Ferreirós CM, Criado MT, Pintor M. Reliability of laboratory models in the analysis of $\mathrm{Tbp} 2$ and other meningococcal antigens. FEMS Immunol Med Microbiol 1994; 9: 299-305. 